\title{
Sensory evaluation of fermented dairy beverages supplemented with iron and added by Cerrado fruit pulps
}

\author{
Julliane Souza Barbosa FIGUEIREDO', Grazielle Layanne Mendes SANTOS², João Pedro Antunes LOPES², \\ Larissa Bessa FERNANDES ${ }^{2}$, Fabiane Neves SILVA², Raquel Borges FARIA², Ana Carolina Santos ROCHA², \\ Paula Karoline Soares FARIAS², William James Nogueira LIMA², Carla Adriana Ferreira DURÃES², \\ Alessandra Rejane Ericsson de Oliveira XAVIER ${ }^{1}$, Bruna Mara Aparecida de CARVALHO ${ }^{2}$, \\ Roberta Torres CARELI ${ }^{2}$, Anna Christina de ALMEIDA², Igor Viana BRANDI
}

\begin{abstract}
Anemia due to iron deficiency is the most common in the world being characterized as a significant public health issue. Therefore, its prevention and treatment are considered important before it becomes either chronic or grievous; the interventions with superior potential are the medical supplementation with iron salts as well as food mineral enhancement. The objectives of this study were to develop fermented dairy beverages supplemented with iron and added by Cerrado fruit pulps: cagaita (Eugenia dysenterica), coquinho-azedo (Butia capitata), tamarindo (Tamarindus indica), and umbu (Spondias tuberosa). In addition, the research intended to evaluate the acceptance of these beverages by children and adolescents from public schools in the city of Montes Claros (MG). The methodology consisted in the production of dairy beverages followed by the evaluation of their quality through physicochemical and microbiological analyses. Posteriorly, children and adolescents assessed the sensorial acceptance. The analyses performed presented satisfactory results for physicochemical and microbiological properties regarding the acceptance of the product. The cagaita and coquinho azedo based dairy beverages were the most accepted whether compared with tamarindo and umbu beverages. The fermented dairy beverage supplemented with iron and added by Cerrado fruits come up as a feasible alternative for dietary supplementation, and can promote beneficial effects in human health due to their sensorial acceptance.
\end{abstract}

Keywords: iron deficiency anemia; food supplementation; dairy beverages; cerrado fruit pulps; quality control.

Practical Application: Fermented dairy beverages supplemented with iron and added by Cerrado fruit pulps.

\section{Introduction}

Iron deficiency is the most common cause of anemia in the world (Camaschella, 2015), being considered an important public health issue (Oliveira et al., 2014). This condition affects mostly preschoolers, adolescents, breastfeeding and pregnant women, and can be determined by life conditions, socioeconomic factors, and individual aspects. Moreover, the symptoms are usually associated with underweight at birth, premature weaning, parasitic infection, and undernourishment (Özdemir, 2015).

The prevention and the treatment of iron deficiency anemia are extremely important before the disorder becomes chronic and grievous (Lozoff et al., 2006). The greatest potential interventions are the medical supplementation and food enhancement with iron salts (Özdemir, 2015). According to Johnson-Wimbley \& Graham (2011), the therapy with iron supplements is unproblematic and affordable. Nonetheless, this treatment could be limited by gastrointestinal collateral effects, such as abdominal discomfort, nausea, and retching. Iron supplements with an enteric coating have been developed with fewer side effects, but these alternative supplements are not that well absorbed.
Food supplementation has been utilized in several countries to represent a practical and cost-effective solution in an attempt to increase the nutritional value of food as well as to prevent dietary deficiencies. The most frequently enriched foods are cereal flours, pasta, rice, and dairy beverages (Vellozo \& Fisberg, 2010; Aaron et al., 2015). Beverages comprising fruits and milk have been arousing increased attention as an iron supplementary option due to their greater acceptance among children and adolescents. These drinks are extremely nutritious and can improve the iron deficiency framework by offering doses that supplement the daily requirement for this specific age range (Le Port et al., 2017).

Whey is a by-product of dairy industries that is usually disposed in sewerage and rivers, causing major polluting effects (Smithers, 2008). However, according to Prazeres et al. (2012), whey is not considered a by-product, but a compound with varied chemical properties due to its great nutritional value. One of the leading alternatives to utilize whey according to Brazilian legislation is the production of fermented dairy beverage, 
which could be enhanced with fruits pulp, or even aromatized. This leads to a more representative sensory acceptance of the product (Brasil, 2005a; Santos et al., 2008).

The consumption of Cerrado fruits and their pulps has been recommended due to their unique sensory characteristics (Paula et al., 2012). In addition their excellent nutritional quality, studies have indicated pharmacological activities, such as anti-inflammatory and analgesic (Suralkar et al., 2012). According to literature reports, these food it are a good source of phenolic compounds featuring antioxidant activity with protective action against the emergence or development of degenerative processes that lead to chronic diseases (Vieira et al., 2011; Morais et al., 2013; Rocha et al., 2013).

Therefore, the objectives of this study were to develop fermented dairy beverages with Cerrado fruit pulps supplemented with iron as well as to evaluate the acceptance of such beverages by children and adolescents studying at public schools in the city of Montes Claros (MG). It was chosen to evaluate the fruits cagaita (Eugenia dysenterica), coquinho-azedo (Butia capitata), tamarindo (Tamarindus indica), and umbu (Spondias tuberosa), due to their high availability in the Cerrado, and to have high nutritional value, besides the flavor characteristic of each fruit.

\section{Materials and methods}

The dairy beverages were produced at the Food Technology Laboratory, Institute of Agricultural Sciences, Federal University of Minas Gerais, in Montes Claros, according with the methodology proposed by Almeida et al. (2001), with a few modifications.

Four dairy beverages were prepared with Cerrado fruit pulps, namely: cagaita (Eugenia dysenterica), coquinho azedo (Butia capitata), tamarindo (Tamarindus indica), and umbu (Spondias tuberosa). The produced beverages consisted of reconstituted skim milk (39.04\%), reconstituted whey (39.04\%), sucrose $(10.00 \%)$, and modified starch $(0.80 \%)$. This first mixture received heat treatment $\left(65^{\circ} \mathrm{C}\right.$ for 30 minutes), with subsequent cooling $\left(43^{\circ} \mathrm{C}\right)$ and inoculation of the thermophilic lactic acid culture DVS (1.00\%) proceeding from Christian Hansen do Brasil, containing lyophilized granules of mixed Streptococcus thermophilus and Lactobacillus delbrueckii subsp. bulgaricus strains.

Afterwards, the mixture was incubated at $43{ }^{\circ} \mathrm{C}$ for 5 hours followed by cooling at $8{ }^{\circ} \mathrm{C}$ for 5 hours as well. The clot was agitated and pasteurized fruit pulp $(10.00 \%)$, potassium sorbate preservative $(0.10 \%)$, and iron amino acid chelate $(0.003 \%)$ were added, followed by homogenization. Then, the beverages were filled in $300 \mathrm{~mL}$ plastic bottle packages, identified, and stored under refrigeration $\left(5^{\circ} \mathrm{C}\right)$.

An iron content of $3 \mathrm{mg}$ per $100 \mathrm{~mL}$ of dairy beverage was established, which corresponds to $33 \%$ of daily recommendation for children from 7 to 10 years as required by the Resolution RDC N ${ }^{\circ} 269$ from Brazilian National Health Surveillance Agency (Brasil, 2005b).

\subsection{Assessment of dairy beverage stability}

To evaluate the dairy beverage stability, several physicochemical assays were carried out in the first day of production as well as in the twentieth day of storage. Moreover, microbiological tests were also performed before the dairy beverage consumption. A completely randomized experimental design was applied to the physicochemical analyses with three repetitions for each flavor. Triplicates were performed for each repetition.

\subsection{Physicochemical analyses}

The physicochemical analyses were carried out in accordance with the Normative Instruction $n^{\circ} 68$ of the Ministry of Agriculture, Livestock, and Supply (Brasil, 2006). The samples were randomly collected, homogenized and analyzed as to $\mathrm{pH}$ and titratable acidity (\% lactic acid). The measurements were performed in triplicates with a digital $\mathrm{pH}$ meter and via titration for $\mathrm{pH}$ and titratable acidity, respectively.

\subsection{Microbiological analyses}

The microbiological determinations were accomplished according with the methodology described by the Normative Instruction $n^{\circ} 62$ of the Ministry of Agriculture, Livestock, and Supply (Brasil, 2003). It assesses the viability of lactic acid bacteria as well as the occurrence of thermotolerant coliforms and Salmonella spp, as recommended by the Resolution RDC $\mathrm{n}^{\circ} 12$ from the Brazilian National Health Surveillance Agency (Brasil, 2001).

\subsection{Sensory evaluation}

A cross sectional exploratory study has been realized. According to Cunha et al. (2013) in previous studies, the school was chosen randomly using as a criterion the socioeconomic reality of the selected neighborhood. The sensory evaluation was performed at the Dominguinhos Pereira municipal school (CAIC do Maracanã), in Montes Claros county. This school was chosen because the students already had experience in sensory analysis in other studies realized in this institution. Seventy-one untrained panelists were selected from elementary school, aged between 6 and 14. Their parents or legal guardians previously received the terms of Informed Consent and Assent approved by the Ethics in Research Committee (COEP), UFMG under CAAE n 38664014.1.0000.5149.

Four samples (cagaita, coquinho azedo, tamarindo, and umbu) were presented to the panelists, who evaluated them through an acceptance test with a 5-point facial hedonic scale (5 - liked extremely, 4 - liked, 3 - indifferent, 2 - disliked, 1 - disliked extremely). To perform the sensory evaluation, $50 \mathrm{~mL}$ of each sample were offered to each tester in unidentified white disposable cups (Cunha et al., 2013). Water at room temperature and crackers were offered to mitigate the influence of one sample on another.

\subsection{Statistical analysis of the data}

Analysis of Variance (ANOVA) with randomized blocks design was used for the statistical analysis. The data were tabulated and analyzed in the System Statistical Analysis (SAS Institute Inc., 2004) statistical software, version 9.1, at a significance level of $5 \%$ by the $\mathrm{F}$ test. To determine which beverage obtained the greatest acceptance, the Tukey test was carried out at a significance level of $5 \%$. 


\section{Results and discussion}

\subsection{Dairy beverage stability}

The $\mathrm{pH}$ and titratable acidity results are presented in Table 1. The $\mathrm{pH}$ value was increased whereas the acidity was reduced only in the tamarindo based dairy beverage. An opposite situation was observed in the other beverages.

According to Oliveira et al. (2002), $\mathrm{pH}$ variations lower than 0.12 throughout the storage period are minor decreases, whereas variations between 0.14 and 0.32 are perceptive decreases. Therefore, the dairy beverages added by cagaita and coquinho azedo presented perceptive decreases, while the umbu one demonstrated a significant $\mathrm{pH}$ variation. Although the $\mathrm{pH}$ is not an official parameter to assess the quality of dairy beverages, it can provide additional information. Values between 4.0 and 4.4 are close to optimal since the product in this range is not classified as excessively acid (Rodrigues et al., 2010).

Vinderola et al. (2000) pointed out that the $\mathrm{pH}$ value relates to the final product's visual aspects during its storage under refrigeration. A strict control is essential; therefore, there is neither separation of high acidification phases influenced by the fermentation time, nor alterations in the sensorial characteristics, that might results in an undesirable product.

The acidity values of all samples were higher than $0.70-0.72 \%$, which is the ideal range of lactic acid (Tamine \& Robinson, 1991). According to Caldeira et al. (2010), differences in the acidity values for different products could be related with the type, the concentration, the activity of the used culture, the quantity of utilized serum, and the storage period. The cooling temperature, the storage duration, and the variation in the $\mathrm{pH}$ values are factors that lead to an increase or decrease in the degree of the product's acidity changes (Lima, 2011).

These changes in $\mathrm{pH}$ and acidity values could be justified by the fact that Lactobacillus acidifies the culture medium faster. For $\mathrm{pH}$ between 4 and 4.2, Streptococcus growth is inhibited, but Lactobacillus maintain its fermentation (Moreira et al., 1999; Ferreira, 2005), promoting the constant production of lactic acid. This results in a reduction of $\mathrm{pH}$ in the culture medium and lead to a continuous increase in titratable acidity.

Table 2 comes up with the initial and final counts of lactic acid bacteria. The count of viable lactic acid bacteria was reduced throughout storage; however, the final count matched the current legislation that requires at least $10^{6} \mathrm{CFU} / \mathrm{mL}$ (Brasil, 2000). The lactic acid bacteria are responsible for an improvement in both food texture and sensory profile whereas there is a reduction in the lactose content. This promotes an improvement in food digestibility as well as an increase in the lactic acid production that contributes to the aroma and texture of the final product (Pescuma et al., 2010; Messia et al., 2007).

As shown in Table 3, the microbiological analyses are in accordance with the standards established by the current legislation ( $<10 \mathrm{MPN} / \mathrm{g}$ for coliforms and absence of Salmonella for each $25 \mathrm{~g}$ of food). So, the beverages are considered suitable for human consumption (Brasil, 2003). This fact demonstrates the product's quality and corroborates that the raw material and the formulation of the product respect adequate hygiene conditions.

\subsection{Sensory evaluation}

Seventy-one children and adolescents participated in the sensory evaluation of fermented dairy beverages, whose participation was previously consented by their parents or legal guardians. The panelists were characterized by being $63 \%$ males and $37 \%$ females, wherein $70 \%$ were children aged between 6 and 11 years, and $30 \%$ adolescents aged between 12 and 14 years.

The dairy beverages from the Cerrado fruits were well accepted by both groups, whose acceptance varied between the hedonic terms "liked" and "liked extremely". Figure 1 presents the sensory outcome for the fermented dairy beverages. It is observed that cagaita and coquinho azedo based beverages were the most accepted ones, exceeding the acceptances of the beverages based on tamarindo and umbu. This fact can be corroborated in Table 4, where the greater scores are attributed to cagaita and coquinho azedo beverages, which in turn significantly differed $(\mathrm{p}<0.05)$ from the tamarindo and umbu beverages.

Table 1. $\mathrm{pH}$ and acidity (\% of lactic acid) of fermented dairy beverages.

\begin{tabular}{ccccc}
\hline Beverage & $\mathrm{pH}_{\text {initial }}{ }^{*}$ & $\mathrm{pH}_{\text {final }}{ }^{*}$ & ACIDITY $_{\text {initial }}^{*}$ & ACIDITY $_{\text {final }}^{* *}$ \\
\hline Cagaita & 4.36 & 4.23 & 0.74 & 0.90 \\
Coquinho azedo & 4.60 & 4.38 & 0.73 & 0.76 \\
Tamarindo & 3.93 & 4.03 & 1.04 & 0.97 \\
Umbu & 4.39 & 3.71 & 0.96 & 1.05 \\
\hline
\end{tabular}

${ }^{*}$ initial $=$ day 0 ; ${ }^{* *}$ final $=$ day 21 .

Table 2. Viability of lactic acid bacteria (CFU/mL).

\begin{tabular}{ccc}
\hline Beverage & COUNT $_{\text {initial }}^{*}$ & COUNT $_{\text {final }}^{* *}$ \\
\hline Cagaita & $1.62 \times 10^{8}$ & $1.0 \times 10^{6}$ \\
Coquinho azedo & $1.58 \times 10^{8}$ & $3.0 \times 10^{6}$ \\
Tamarindo & $2.05 \times 10^{8}$ & $1.0 \times 10^{6}$ \\
Umbu & $3.55 \times 10^{8}$ & $1.5 \times 10^{6}$ \\
\hline
\end{tabular}

${ }^{*}$ initial $=$ day $0 ;{ }^{* *}$ final $=$ day 21 .

Table 3. Microbiological analyses of fermented dairy beverages.

\begin{tabular}{cccc}
\hline Beverage & $\begin{array}{c}\text { Total coliforms } \\
(\mathrm{MPN} / \mathrm{g})\end{array}$ & $\begin{array}{c}\text { Fecal coliforms } \\
(\mathrm{MPN} / \mathrm{g})\end{array}$ & Salmonella sp \\
\hline Cagaita & $<3$ & $<3$ & - \\
Coquinho-azedo & $<3$ & $<3$ & - \\
Tamarindo & $<3$ & $<3$ & - \\
Umbu & $<3$ & $<3$ & - \\
\hline
\end{tabular}

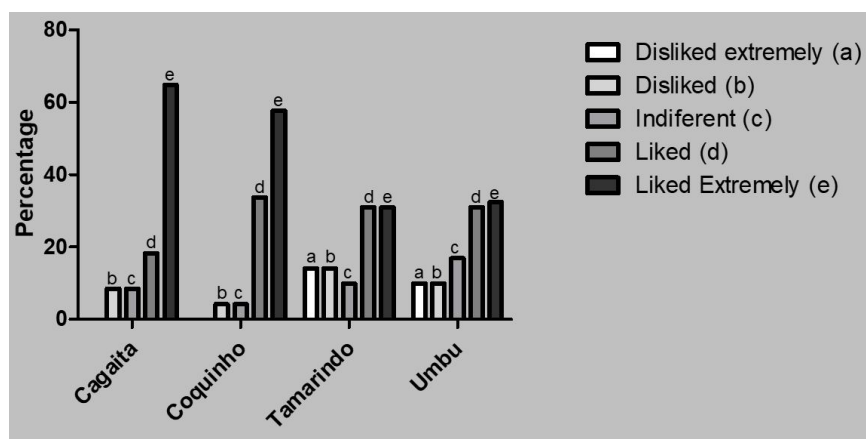

Figure 1. Sensory evaluation outcome for fermented dairy beverages. 


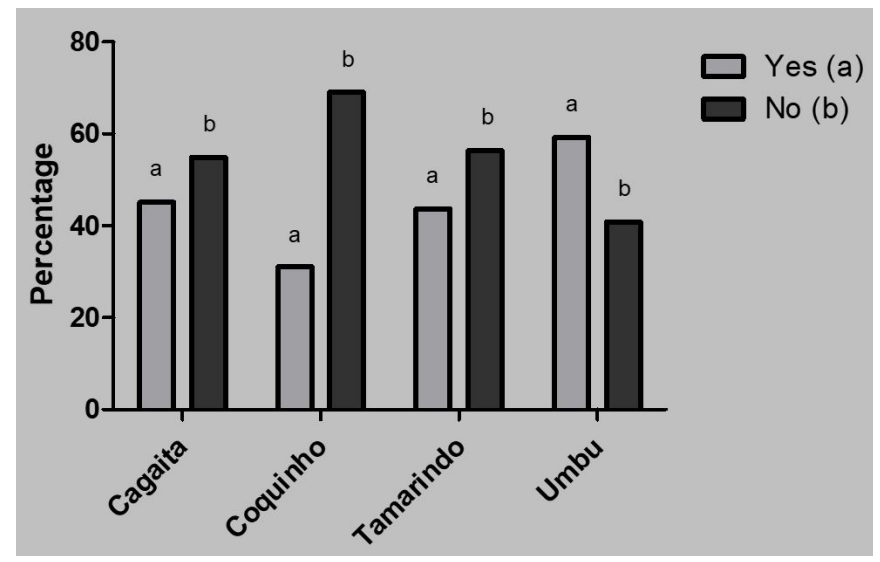

Figure 2. Iron flavor perception in the fermented dairy beverages.

Table 4. Statistics for the sensory evaluation data (mean comparison test).

\begin{tabular}{ccc}
\hline Beverage & Mean value & Tukey group \\
\hline Cagaita & 4.3803 & $\mathrm{~A}$ \\
Coquinho azedo & 4.4648 & $\mathrm{~A}$ \\
Tamarindo & 3.6761 & $\mathrm{~B}$ \\
Umbu & 3.5070 & $\mathrm{~B}$ \\
\hline
\end{tabular}

LSD 0.4575 (Least Significant Difference).

The ANOVA pointed out the relation between the acceptance of fermented dairy beverages and both gender and age. As a result, a relative probability lower than 0.05 was obtained, which infers that there was a statistical difference meaning that the gender and age of the judges interfered in the score attributed for each beverage. In other words, it may be stated that the preference for a particular fermented dairy beverage flavor depends on the consumer's age and gender.

Although iron amino acid chelate is recommended for supplementation due to its lack of influence in the sensory characteristics of the final product, Figure 2 demonstrates that a characteristic iron flavor was noticed by the panelists, which was greater in the umbu based dairy beverage.

Moreover, another advantage of the use of iron amino acid chelate is the maintenance of its stability in both acidic and alkaline media. This means gastrointestinal tolerance and absence of any gastrointestinal symptoms (Tuma et al., 2003).

\section{Conclusion}

The use of Cerrado fruit pulps and whey as raw materials denotes a technologically feasible alternative because these products play significant economic - through marketing and commercialization - and nutritional -because of the nutrients found in their composition - roles.

The performed analyses allow one to conclude that the objectives of this research were achieved concerning the microbiological and physicochemical analyses, which presented desirable results regarding the product acceptance. The sensory outcome indicated a remarkable sensory acceptance with a potential perspective of improvements in future studies.
Therefore, the whey-based dairy beverage incorporated with Cerrado fruit pulps and supplemented with iron can promote beneficial effects to human health, denoting a feasible alternative to food supplementation. Finally, it is expected that this food generate technological and nutritional benefits due to its low-cost and nutritious constituents, adding value to regionally native fruits through their application in products that results in health benefits to the population.

\section{Acknowledgements}

This work was realized with the support of the CAPES, FAPEMIG, CNPq, Ministério da Educação - Brasil (PROEXT), and Pró-Reitoria de Pesquisa da UFMG, Pró-Reitoria de Extensão da UFMG and collaboration of Dominguinhos Pereira municipal school.

\section{References}

Aaron, G., Dror, D., \& Yang, Z. (2015). Multiple-micronutrient fortified non-dairy beverage interventions reduce the risk of anemia and iron deficiency in school-aged children in low-middle income countries: a systematic review and meta-analysis. Nutrients, 7(5), 3847-3868. http://dx.doi.org/10.3390/nu7053847. PMid:26007336.

Almeida, K. E., Bonassi, I. A., \& Roça, R. O. (2001). Características físicas e químicas de bebidas lácteas fermentadas e preparadas com soro de queijo minas frescal. Food Science and Technology (Campinas), 21(2), 187-192. http://dx.doi.org/10.1590/S0101-20612001000200012.

Brasil. Ministério da Agricultura, Pecuária e Abastecimento. (2000, November 27). Oficializa os padrões de identidade e qualidade (PIQ) de leites fermentados (Resolução no 5 , de 13 de novembro de 2000). Diário Oficial [da] República Federativa do Brasil. Retrieved from http://www.engetecno.com.br/port/legislacao/leite_piq_leite_ fermentado.htm

Brasil. Agência Nacional de Vigilância Sanitária - ANVISA. (2001, January 10). Aprova o Regulamento Técnico sobre padrões microbiológicos para alimentos (Resolução RDC n ${ }^{\circ} 12$, de 02 de instrução normativa ${ }^{\circ} 16$, de 23 de agosto de 2005). Diário Oficial [da] República Federativa do Brasil. Retrieved from http://portal. anvisa.gov.br/wps/wcm/connect/a47bab8047458b909541d53fbc4 c6735/R DC_12_2001.pdf?MOD=AJPERES

Brasil. Ministério da Agricultura, Pecuária e Abastecimento. (2003, August 26). Oficializa os Métodos Analíticos Oficiais para Análises Microbiológicas para Controle de Produtos de Origem Animal e Água (Instrução normativa no 62, de 26 de agosto de 2003). Diário Oficial [da] República Federativa do Brasil. Retrieved from http:// www.hidrolabor.com.br/IN62.pdf

Brasil. Ministério da Agricultura, Pecuária e Abastecimento. (2005a, August 24). Instrução Normativa no 16, de 23 de agosto de 2005. Regulamento técnico de identidade e qualidade de bebida láctea. Diário Oficial [da] República Federativa do Brasil. Retrieved from http://www.cda.sp.gov.br/www/legislacoes/popup.php?action=view\& idleg $=702$

Brasil. Agência Nacional de Vigilância Sanitária - ANVISA. (2005b, September 23). O "regulamento técnico sobre a ingestão diária recomendada (IDR) de proteína, vitaminas e minerais" (Resolução RDC n²69, de 22 de setembro de 2005). Diário Oficial [da] República Federativa do Brasil. Retrieved from http://portal.anvisa. gov.br/wps/wcm/connect/1884970047457811857dd53fbc4c6735/ RDC_269_2005.pdf?MOD=AJPERES 
Brasil. Ministério da Agricultura, Pecuária e Abastecimento. (2006, December 14). Oficializa os Métodos Analíticos Oficiais Físico-Químicos, para Controle de Leite e Produtos Lácteos determinando que sejam utilizados nos Laboratórios Nacionais Agropecuários (Instrução Normativa $\mathrm{n}^{\circ}$ 68, de 12 de dezembro de 2006). Diário Oficial [da] República Federativa do Brasil. Retrieved from https://www.legisweb. com.br/legislacao/?id=76819

Caldeira, L. A., Ferrão, S. P. B., Fernandes, S. A. A. F., Magnavita, A. P. A., \& Santos, T. D. R. (2010). Desenvolvimento de bebida láctea sabor morango utilizando diferentes níveis de iogurte e soro lácteo obtidos com leite de búfala. Ciência Rural, 40(10), 2193-2198. http:// dx.doi.org/10.1590/S0103-84782010005000176.

Camaschella, C. M. D. (2015). Iron-deficiency anemia. The New England Journal of Medicine, 372(19), 1832-1843. http://dx.doi.org/10.1056/ NEJMra1401038. PMid:25946282.

Cunha, D. T., Botelho, R. B. A., Brito, R. R., Pineli, L. L. O., \& Stedefeldt, E. (2013). Métodos para aplicar las pruebas de aceptación para la alimentación escolar: validación de la tarjeta lúdica. Revista Chilena de Nutrición, 40(4), 357-363. http://dx.doi.org/10.4067/ S0717-75182013000400005.

Ferreira, C. L. L. F. (2005). Produtos lácteos fermentados - aspectos bioquímicos e tecnológicos. In C. L. L. F. Ferreira (Ed.), Principais tipos de fermentação em produtos de laticínios (3. ed., pp. 40-43). Viçosa: UFV.

Johnson-Wimbley, T. D., \& Graham, D. Y. (2011). Diagnosis and management of iron deficiency anemia in the 21 st century. Therapeutic Advances in Gastroenterology, 4(3), 177-184. http:// dx.doi.org/10.1177/1756283X11398736. PMid:21694802.

Le Port, A., Bernard, T., Hidrobo, M., Birba, O., Rawat, R., \& Ruel, M. T. (2017). Delivery of iron-fortified yoghurt, through a dairy value chain program, increases hemoglobin concentration among children 24 to 59 months old in Northern Senegal: a cluster-randomized control trial. PLoS One, 12(2), e0172198. http://dx.doi.org/10.1371/ journal.pone.0172198. PMid:28245227.

Lima, C. M. F. (2011). Monitoramento de temperaturas de equipamentos de refrigeração em supermercados da cidade de Maceió - AL. Revista Higiene Alimentar, 25(194-195):35-39.

Lozoff, B., Jimenez, E., \& Smith, J. B. (2006). Double burden of iron deficiency in infancy and low socioeconomic status: a longitudinal analysis of cognitive test scores to age 19 years. Archives of Pediatrics \& Adolescent Medicine, 160(11), 1108-1113. http://dx.doi.org/10.1001/ archpedi.160.11.1108. PMid:17088512.

Messia, M.C., Candigliota, T., Marconi, E. (2007). Assessment of quality and technological characterization of lactose-hydrolyzed milk. Food Chemistry, 104(3):910-917. http://dx.doi.org/10.1016/j. foodchem.2006.12.045.

Morais, M. N., Silva, A. C. R., Araújo, C. R. R., Esteves, E. A., \& Dessimoni-Pinto, N. A. V. (2013). Determinação do potencial antioxidante in vitro de frutos do Cerrado brasileiro. Revista Brasileira de Fruticultura, 35(2), 355-360. http://dx.doi.org/10.1590/ S0100-29452013000200004.

Moreira, S. R., Schwan, R. F., Carvalho, E. P., \& Ferreira, C. (1999). Análise microbiológica e química de iogurtes comercializados em lavras - MG. Food Science and Technology (Campinas), 19(1), 147152. http://dx.doi.org/10.1590/S0101-20611999000100027.

Oliveira, M. N., Sodini, I., Remeuf, F., Tissier, J. P., \& Corrieu, G. (2002). Manufacture of fermented lactic beverages containing probiotic cultures. Journal of Food Science, 67(6), 2336-2341. http://dx.doi. org/10.1111/j.1365-2621.2002.tb09550.x.
Oliveira, T. S. C., Silva, M. C., Santos, J. N., Rocha, D. S., Alves, C. R. L., Capanema, F. D., \& Lamounier, J. A. (2014). Anemia among preschool children - a public health problem in Belo Horizonte, Brazil. Ciencia \& Saude Coletiva, 19(1), 59-66. http://dx.doi. org/10.1590/1413-81232014191.1927. PMid:24473603.

Özdemir, N. (2015). Iron deficiency anemia from diagnosis to treatment in children. Turk Pediatri Ars, 50(1), 11-19. http://dx.doi.org/10.5152/ tpa.2015.2337. PMid:26078692.

Paula, B., Carvalho, C. D. Fo., Matta, V. M., Menezes, J. S., Lima, P. C., Pinto, C. O., \& Conceição, L. E. M. G. (2012). Produção e caracterização físico-química de fermentado de umbu. Ciência Rural, 42(9), 16881693. http://dx.doi.org/10.1590/S0103-84782012000900027.

Pescuma, M., Hébert, E. M., Mozzi, F., \& Font de Valdez, G. (2010). Functional fermented whey-based beverage using lactic acid bacteria. International Journal of Food Microbiology, 141(1-2):73-81. https:// doi.org/10.1016/j.ijfoodmicro.2010.04.011.

Prazeres, A. R., Carvalho, F., \& Rivas, J. (2012). Cheese whey management: a review. Journal of Environmental Management, 110, 48-68. http:// dx.doi.org/10.1016/j.jenvman.2012.05.018. PMid:22721610.

Rocha, M. S., Figueiredo, R. W., Araujo, M. A. M., \& Moreira-Araujo, R. S. R. (2013). Caracterização físico-química e atividade antioxidante (in vitro) de frutos do cerrado Piauiense. Revista Brasileira de Fruticultura, 35(4), 933-941. http://dx.doi.org/10.1590/S010029452013000400003.

Rodrigues, L. A., Ortolani, M. B. T., \& Nero, L. A. (2010). Microbiological quality of yoghurt commercialized in Viçosa, Minas Gerais, Brazil. African Journal of Microbiology Research, 4(3), 210-213.

Santos, C.T., Costa, A.R., Reis, G.C., Fontan, R.C.I., Bonomo, R.C.F. (2008). Influência da concentração de soro na aceitação sensorial de bebida láctea fermentada com polpa de manga. Alimentos e Nutrição, 19(1):55-60. http://dx.doi.org/200.145.71.150.

SAS Institute Inc. (2004). SAS OnlineDoc ${ }^{\circledR}$ 9.1.3. Cary: SAS Institute Inc.

Smithers, G. W. (2008). Whey and whey proteins-from 'gutter-togold'. International Dairy Journal, 18(7), 695-704. http://dx.doi. org/10.1016/j.idairyj.2008.03.008.

Suralkar, A.A., Rodge, K.N., Kamble, R.D., Maske, K.S. (2012). Evaluation of anti-inflammatory and analgesic activities of Tamarindus indica seeds. International Journal of Pharmaceutical Sciences and Drug Research, 4(3):213-217. http://dx.doi.org/0975-248X.

Tamine, A. Y., \& Robinson, R. K. (1991). Yogur: ciencia y tecnologia (368 p.). Zaragoza: Editorial Acribia S.A.

Tuma, B. R., Yuyama, L. K. O., Aguiar, J. P. L., \& Marques, H. O. (2003). Impacto da farinha de mandioca fortificada com ferro aminoácido quelato no nível de hemoglobina de pré-escolares. Revista de Nutrição, 16(1), 29-39. http://dx.doi.org/10.1590/S1415-52732003000100004.

Vellozo, E. P., \& Fisberg, M. (2010). O impacto da fortificação de alimentos na prevenção da deficiência de ferro. Revista Brasileira de Hematologia e Hemoterapia, 32, 134-139. http://dx.doi.org/10.1590/ S1516-84842010005000069.

Vieira, L. M., Sousa, M. S. B., Mancini-Filho, J., \& Lima, A. (2011). Fenólicos totais e capacidade antioxidante in vitro de polpas de frutos tropicais. Revista Brasileira de Fruticultura, 33(3), 888-897. http://dx.doi.org/10.1590/S0100-29452011005000099.

Vinderola, C.G., Bailo, N., Reinheimer, J.A. (2000). Survival of probiotic in Argentina yogurts during refrigerate storage. Food Research International, 33(2):97-102. http://dx.doi.org/10.16/ S0963-9969(00)00011-9. 